\title{
5 What's the Message? Das AFSC zwischen Home und Foreign Service 1919-1935
}

An einem Tag im Juni 1930 stand Clarence Pickett an der Reling des Transatlantikliners Europa und betrachtete sinnierend die im Nebel vorbeiziehende Küste Long Islands. An diesem Tag kehrte der seit einem Jahr amtierende Generalsekretär des AFSC von einer mehr als zweimonatigen Reise zurück, die ihm einen ersten unmittelbaren Eindruck von der auswärtigen Arbeit der Quäker hatte verschaffen sollen. Er hatte in Europa eine Welt im Aufbruch erlebt und in der Mitte von allem „our little chain of Centers“, die versuchten diese Welt auf eine bessere Bahn zu bringen. Seine Aussicht war optimistisch: Was er gesehen hatte, machte ihn zuversichtlich, dass die begonnene Arbeit, so sie weitergeführt würde einen gewichtigen Beitrag leisten könnte „not only in bringing peace but new meaning of the life to the world". ${ }^{1}$

Picketts Zuversicht mochte manchen überraschen angesichts der Tatsache, dass er in ein Land zurückkehrte, das seit Ende des Vorjahres im Begriff war, tief in die Great Depression zu gleiten und den Blick mehr denn je nach innen richtete. Die großen Hilfsoperationen des AFSC lagen zu diesem Zeitpunkt bereits mehrere Jahre zurück, ohne dass ihnen weitere Einsätze gefolgt wären. Und mehr als das: In den vorangegangenen Jahren hatten Wilbur Thomas und sein Nachfolger Pickett einen tiefgreifenden Wandel des Komitees moderiert, in dem dieses sich von einer Institution des foreign relief zu einer Organisation entwickelte, die den home service, sprich: die Arbeit in den USA selbst als sein Haupttätigkeitsfeld zu betrachten begann. Wie zu zeigen sein wird, waren außen und innen, foreign und domestic freilich selten klar voneinander zu trennen, sondern bedingten und beeinflussten sich auf vielfache Weise wechselseitig. In der Diskussion um den Sinn und Zweck des AFSC, um seinen Auftrag und sein ethisches Fundament, um seine Position in der Welt und seine Haltung zu Regierung und Staat sowie um das (richtige) Verhältnis zwischen relief und message work waren die Erfahrungen der auswärtigen Hilfseinsätze und des heimischen service untrennbar miteinander verwoben. Dabei stellte sich die 1926 in einem Memorandum aufgeworfene Frage „(H)as the Service Committee a vital message, an effective method and an ultimate motive?" immer wieder aufs Neue. ${ }^{2}$

1 Tagebucheintrag Clarence Pickett 15/06/1930, in: AFSCA, Clarence Pickett Journals 1920 - 1936 (Trip to Europe 1930).

2 Memorandum for the Committee on Interpretation and Publicity, n.n. 1926, in: AFSCA, AFSC Minutes 1926.

Ә OpenAccess. (C) 2022 Daniel Maul, publiziert von De Gruyter. (cc) BY-NC-ND Dieses Werk ist lizenziert unter einer Creative Commons Namensnennung - 4.0 International Lizenz.

https://doi.org/10.1515/9783110675788-007 


\section{Die Diskussionen um die Zukunft des AFSC 1921-1929}

Diskussionen um die Zukunft der internationalen Arbeit des AFSC und der Organisation selbst hatten das Komitee praktisch seit seinen Anfängen begleitet. ${ }^{3}$ Noch während die Hilfseinsätze in Deutschland und der Sowjetunion in vollem Gang waren, sah sich das AFSC diesbezüglich zu einer Erklärung bemüßigt: Aufgabe des Komitees sei es nun, „to maintain the interest in world problems created by the joint work of Friends“. Dafür brauche es auch weiterhin eine „permanent organization for social and religious work“. Es gelte darum, auch nach Ende der derzeitigen europäischen Einsätze einen „nucleus“ zu erhalten, „which could be expanded as occasion demands and thus enable the whole group of Friends to give united service on any particular occasion“. ${ }^{4}$

Einigkeit bestand weiterhin darin, dass message work in allen zukünftigen Hilfsaktionen wieder eine hervorgehobenere Rolle spielen sollte. Im Juli 1923 warf ein Grundsatzpapier des AFSC-Executive Board mit Blick auf die Hilfsaktionen in Russland und Polen die Frage auf, ,whether or not this particular type of work would best open up the way for message work either this year or in the succeeding years“. Das Protokoll vermerkte, dass mehrheitlich die Auffassung bestand, ,that we ought not to let our relief work become an end in itself, but that we should always endeavor to make it contributory to the larger service of creating more good will in the world“. 5

In einem weiteren Grundsatzpapier von Ende 1924 fand sich dies nochmals bestätigt. Das AFSC wolle seine durch die humanitäre Hilfe erworbene Reputation nutzen, um auch weiterhin Hilfe dort zu leisten, wo sie benötigt würde, und in der Zwischenzeit den Schwerpunkt seiner internationalen Arbeit auf message work verlagern, verstanden insbesondere als umfassender Friedens- und Versöhnungsdienst:

3 Frost, „Our Deeds carry our Message“, 33-34. Im folgenden Teilabschnitt zu den internen Diskussionen und zur Entwicklung eines Home Service stütze ich mich vorwiegend neben den AFSC Jahresberichten und Bulletins auf Barnes Überblicksdarstellung. Barnes, A Centennial History of the American Friends Service Committee, 60 -73. Darüber hinaus gibt insbesondere Guy Aikens bislang noch unveröffentlichte Dissertation einen sehr guten Einblick in die Diskussionen um die religiöse Ausrichtung des AFSC vor dem Hintergrund breiterer Entwicklungen einer „social christianity“ in den USA vom Ersten Weltkrieg bis in die Jahre des New Deal. Guy Aiken, „Social Christianity and the American Friends Service Committee's Pacifist Humanitarianism in Germany and Appalachia, 1919-1941.“ Ph.D., University of Virginia, 2017.

4 Erklärung 1922, in: AFSCA, AFSC Minutes 1922.

5 Grundsätzliches Statement des Executive Board 11/7/1923, in: AFSCA, AFSC Minutes 1923. 
„It is our conviction that now when the world has come to believe that Friends have a positive mission in the world today it is our simple duty to take up carefully, prayerfully and systematically these deep lying fundamental issues of life to see whether we cannot carry our ideals more effectively into the life of the world and whether we cannot become better and more vital organising the Spirit of Christ."

Message work bedeutete freilich weiterhin unterschiedliche Dinge für unterschiedliche Gruppen innerhalb des Quäkertums. Im Hintergrund tobte in den 1920er Jahren ein verschärfter Deutungskampf um die Ausrichtung zwischen Orthodoxen, Evangelikalen und Modernisten, wobei die Grenzen nicht immer klar definiert waren: Nicht wenige der sozial aktivistischen und progressiven Quäker hatten (wie etwa Carolena Wood) evangelikale Neigungen, umgekehrt waren viele orthodoxe Quäker, wie eingangs gezeigt wurde, nicht evangelikal und sahen entsprechende Tendenzen ebenso kritisch wie die modernistische Theologie und den als invasiv empfundenen Aktivismus des AFSC. Das AFSC war in dieser Gemengelage somit alles gleichzeitig: Partei, Austragungsort und Klammer für die unterschiedlichen Fraktionen. Auf der einen Seite erschien das AFSC zunehmend als eine Vertretung des liberalen und sozialaktivistischen Flügels der Quäker, auf der anderen war das Komitee intensiv bemüht, weiterhin die Einheit über alle Flügel hinweg aufrechtzuerhalten. Auf der einen Seite war das AFSC ohne Zweifel ein Teil des - den Werten der „social christianity“ verpflichteten - liberalen protestantischen Establishments an der Ostküste. ${ }^{7}$ Die meisten Mitglieder vertraten, was Guy Aiken als Elemente einer modernistischen Theologie zusammenfasst - sie bejahten die darwinistische Evolutionstheorie, eine historischkritische Lesart der Bibel und die immanente Gegenwart Gottes in der Geschichte. Auch standen sie für eine ähnlich progressive, liberale Agenda - „denounced racial oppression and cutthroat capitalism“. ${ }^{8}$ Auf der anderen Seite blieb das AFSC jedoch ein im christlichen Glauben verankertes Komitee. Wiederholt wurde dies in den Stellungnahmen des AFSC zu internationalen und gesellschaftlichen Fragen deutlich. ${ }^{9}$ Probleme ergaben sich eher aus dem Anspruch des AFSC, auch eine Vertretung für die evangelikalen und konservativen Quäker aus dem Rest des Landes sein zu wollen.

6 AFSC Minutes 2/12/1924, in: AFSCA, AFSC Minutes 1924.

7 Aiken, „Social Christianity,“ 67-69; William R. Hutchinson, The Modernist Impulse in American Protestantism (Cambridge, MA: Harvard University Press, 1976).

8 Aiken, „Social Christianity,“ 11.

9 Siehe hierzu etwa die von Wilbur Thomas im Namen des AFSC verfasste Broschüre The Biblical Basis of Friends Opposition to War, die den Pazifismus der Quäker an die biblische Überlieferung knüpfte, in: AFSC- Bulletin 77 (1928). 
Vor diesem Hintergrund waren auch die Diskussionen um die Fortsetzung und den künftigen Charakter der internationalen Arbeit nur ein Teil einer noch umfassenderen Debatte um die Zukunft des AFSC. Die eigentliche Frage für viele lautete, ob und wenn ja welche Funktionen das AFSC zu Hause, das heißt in den USA selbst ausüben sollte. Pläne zum Aufbau eines home service hatte es dabei schon unmittelbar nach Ende des Krieges gegeben. Wilbur Thomas hatte dem Komitee 1919 einen Entwurf vorgestellt, demzufolge das AFSC als Schaltzentrale eines umfassenden heimischen Quäkersozialdienstes firmieren sollte. ${ }^{10}$ Von Freiwilligen erstellte Untersuchungen zu unterschiedlichen Problemfeldern, angefangen von den ländlichen Gemeinden bis hin zur Situation in afroamerikanischen und indigenen Gemeinschaften, sollten dafür die Basis bilden. Darüber hinaus strebte Thomas für das AFSC eine Rolle als Koordinator all jener Aktivitäten an, in denen Quäker traditionell engagiert waren, unter anderem in den social settlements der amerikanischen Großstädte, der Anti-Saloon- und Prohibitionsbewegung, bei Reformbemühungen im Gefängniswesen sowie insbesondere innerhalb der verschiedenen Zweige der Friedensbewegung.

Bei der Einrichtung eines home service ging es jedoch noch um etwas anderes. Was Thomas und seine Mitstreiter anstrebten, war, vor allem jungen Quäkern neue Möglichkeiten für „,constructive service“ zu eröffnen: Die Möglichkeiten für einen solchen Dienst im Ausland waren begrenzt und an konkrete Hilfsaktionen gebunden, die Nachfrage von Freiwilligen überstieg bei weitem das Angebot an Einsatzgelegenheiten, wie eine erste Bilanz aus dem Jahr 1926 zeigte. Gerade deshalb war das AFSC bemüht, „to place before young people the various opportunities for real service at home“, einen Dienst, der für die jungen Menschen als Initiationsritus mit Blick auf ihre Position als Quäker in der Welt dienen sollte. Dieser würde sie, so der Gedanke, gleichzeitig zu Bürgern machen, die auf diese Weise ihr Wissen um und ihr Bewusstsein für die „Great American problems“ der Zeit vertiefen konnten. ${ }^{11}$

Bei nicht wenigen Quäkern stießen diese Pläne anfänglich auf Vorbehalte. Vor allem konservativere und evangelikale Friends im Mittleren Westen der USA, aber nicht nur sie, waren skeptisch bis ablehnend. Im Ganzen waren die Einwände gegen eine solche Ausdehnung im Inland sogar größer, als sie es gegenüber den auswärtigen Hilfsoperationen des AFSC jemals gewesen waren: Es war hier - in den USA -, wo die geplante Arbeit in direkte Konkurrenz zu den primär religiös ausgerichteten Aktivitäten der Quäkergemeinden und überregionalen Vereini-

10 Barnes, A Centennial History of the American Friends Service Committee, 55-56. 11 Home Service Bulletin, in: AFSC-Bulletin 61 (1926). 
gungen trat. Hier war es auch, wo sich die Kernfrage nach der Identität und Ausrichtung der Society of Friends stellte.

Den sozialen Aktivismus von Wilbur Thomas und die religiöse Praxis vieler Quäkergemeinden trennte hier eine deutliche Kluft. Vor allem evangelikale Quäker, die klassische Missionsarbeit in den USA und darüber hinaus betrieben, empfanden das AFSC als Eindringling. Es zeigte sich nun erneut auch der geografische Gegensatz: Wenn auch eine Reihe von führenden Mitgliedern des AFSC aus dem Mittleren Westen kamen - der Schwerpunkt lag doch auf der Ostküste. Auch aus diesem Grund fühlten sich viele der Mitglieder, die aus Pennsylvania, Neu-England oder New York kamen, eher als Teil des (liberalen) protestantischen Mainstreams und fremdelten mit den evangelikalen Glaubensgenossen. ${ }^{12}$

Aber auch innerhalb des AFSC bestanden unterschiedliche Auffassungen über den home service, die weder auf theologische noch auf geografische Differenzen zurückzuführen waren. Auch politische Fragen spielten eine Rolle, wie sich 1921 deutlich zeigte, als Wilbur Thomas mit einigen anderen das AFSC als neutrale Kraft in einem heimischen Arbeitskonflikt in Position brachte. Den konkreten Anlass bot ein Streik der Arbeiter in den Kohlegruben Pennsylvanias und West-Virginias, die für höhere Löhne, bessere Arbeitsbedingungen und das Recht auf gewerkschaftliche Organisation in den Ausstand getreten waren. Im Zeichen des „Red Scare“ der Nachkriegsjahre und dem allgemeinen Kampf der Gewerkschaften um Anerkennung wurde die Auseinandersetzung insbesondere auf Seiten der Grubenbesitzer mit großer Härte geführt: Viele Arbeiter fanden sich mit ihren Familien buchstäblich auf der Straße wieder, nachdem die Eigentümer sie aus den grubeneigenen Häusern geworfen hatten. In Zelten hausend, ohne Unterstützung von außen und ohne eine anerkannte Interessenvertretung, mangelte es den Streikenden an essenzieller Versorgung. Anfang Januar 1921 debattierte das AFSC vor diesem Hintergrund einen Aufruf gewerkschaftlicher Gruppen, den Notleidenden nach dem Vorbild der Quäkerspeisungen in Deutschland zu Hilfe zu kommen. Die Quäker, so die Argumentation, die am Ende eine Mehrzahl der Mitglieder des AFSC überzeugte, seien dazu besonders geeignet, da sie aufgrund ihrer in den vorangegangenen Hilfseinsätzen erprobten Neutralität für beide Seiten des Konflikts akzeptabel seien.

Einwände gegen den Einsatz hatte es vor allem von zwei Seiten gegeben. Einige Mitglieder des Komitees, nicht wenige von ihnen selbst Unternehmer, hegten grundsätzliche Vorbehalte gegen gewerkschaftliche Anliegen. Viele befürchteten zudem, dass eine Hilfsaktion zugunsten der notleidenden Familien in den Kohlegebieten, so neutral sie im Ansatz auch sein mochte, automatisch als

12 Aiken, Social Christianity, 104-106. 
Parteinahme für die Streikenden ausgelegt werden würde. Darüber hinaus betrachteten einige im AFSC wie Henry Cadbury industrielle Konflikte von einer theologisch-pazifistischen Warte aus mit den gleichen Augen, mit denen sie auch zwischenstaatliche Konflikte bewerteten. Interessengegensätze könnten, so ihre Sichtweise, nur durch den guten Willen der Konfliktparteien, niemals jedoch durch eine gewalttätige Austragung dieser Konflikte behoben werden. Streiks waren in diesem Sinne eine Form der Gewalt, die ebenso zu verurteilen war wie Sanktionen oder Blockaden auf internationaler Ebene. ${ }^{13}$

Referenzen an die internationale Arbeit des AFSC blieben beim anlaufenden Einsatz allgegenwärtig, umso mehr, als der Beginn des Einsatzes im Juni 1921 zeitlich mit dem Konflikt im Komitee um die Beteiligung an der ARA-Aktion in Russland zusammenfiel. Die Kontroversen im AFSC spiegelten die Diskussionen um die russische Hilfsaktion insofern, als wiederum Wilbur Thomas und eine Reihe anderer im AFSC, deren Sympathien deutlich auf Seiten der Streikenden lagen, einer konservativeren Fraktion gegenüberstanden, die eine solche Positionierung und vor allem die Annäherung des Komitees an linke und gewerkschaftliche Gruppen kritisch sah. Das Hervorheben des unpolitischen Charakters der Aktion und ein Fokus auf das Leid der Kinder (und Familien) der Bergarbeiter, als rhetorische Mittel um die eigene Neutralität zu betonen, waren eine weitere Parallele zu den Hilfseinsätzen in Deutschland und Russland. Dabei war es umgekehrt vor allem der Verweis auf die in Europa geleistete Hilfe, die der Berufung auf die eigene Neutralität und die rein humanitäre Ausrichtung im Angesicht eines hochpolitisierten Konflikts erst Glaubwürdigkeit verlieh.

Eine Presseerklärung des AFSC machte dies deutlich: Genau wie die Kinderspeisung in Deutschland von der Überzeugung getragen worden sei, ,that love and goodwill and not war and hatred would bring about better world conditions“, so werde sich das AFSC nun ,in the same spirit“ den bedürftigen Familien in den Kohlerevieren zuwenden. ${ }^{14}$ Schließlich ergaben sich auch während der Durchführung des Einsatzes immer wieder offensichtliche Rückkopplungen mit der Auslandsarbeit: Die Hilfe wurde nach denselben organisatorischen und wissenschaftlichen Prinzipien durchgeführt; so wurden etwa die Speisepläne nach denselben ernährungswissenschaftlichen Kriterien zusammengestellt wie die in Deutschland.

Ungeachtet der Tatsache, dass der Konflikt im Winter 1921 mit einer Niederlage der Streikenden endete, wobei die Grubenbesitzer auf den Einsatz staatlicher Gewalt hatten zählen können, wurde der Einsatz des AFSC insgesamt als Erfolg

13 Aiken, Social Christianity, 106.

14 Zitiert nach Aiken, Social Christianity, 108. 
gewertet. Es war dem Komitee gelungen, seinen Ruf als neutrale Hilfsorganisation auch auf nationaler Ebene zu stärken. Damit stellte der Einsatz in West-Virginia auch eine frühe Initialzündung für den Aufbau eines home service dar und intensivierte (parallel zum russischen Einsatz) die Kontakte des AFSC in das breitere sozialreformerische und gewerkschaftsnahe Milieu. Wenngleich Konflikte nach innen bestehen blieben, stärkte das Komitee nach außen seinen sozialaktivistischen und liberalen Ruf. So wurde die Hilfsaktion zum Teil der breiteren Debatte um die generelle Ausrichtung und mithin die Zukunft eines Quaker Service.

Im Kern der Diskussionen stand in der Folge weniger, ob es eine Zukunft für das AFSC geben, als vielmehr wie expansiv das Mandat des AFSC sein sollte. Wie sich zeigen sollte, erlangten diejenigen, die für einen umfassenden Quäkerdienst plädierten, langsam die Oberhand: Im Dezember legte die AFSC-Führung ein Memorandum vor, das den Weg für eine grundsätzliche Reform ebnete: Nun, da allgemein anerkannt sei, ,that Friends have a positive mission in the world today“, hieß es einleitend, hätten die Quäker die Pflicht, sich permanent mit der Frage auseinanderzusetzen, ,whether we cannot carry our ideals more effectively into the life of the world“. ${ }^{15}$

Vor diesem Hintergrund enthielt das Papier zwei wesentliche Richtungsentscheidungen: Organisatorisch sollte das AFSC künftig in einen foreign service und einen home service aufgegliedert werden. Gleichzeitig wurde die Friedens- und Versöhnungsarbeit als Querschnittsaufgabe aller Aktivitäten des AFSC definiert. Der Begriff des Peace Work, der als Klammer diente, war dabei bewusst weit gefasst und schloss explizit auch die race relationships ein: „As practical Peace work must deal not with abstract ideas, but with actual human relationships“, hieß es hierzu, ,it is felt that the work of this central committee as its scope expands must become concerned to bring about better, closer and more harmonious relationships between different races both as they meet here in our own country and also as they concern separate nations. " 16 Die Aufgaben eines neu geschaffenen Peace Committee waren es, „to coordinate all our Quaker activities for Peace in all lines of life, to discover fresh and effective ways of presenting peace ideals, to work out plans for practicing and interpreting the way of love, fellowship and reconciliation and to assist all the existing committees and organizations to bring the large constructive spiritual aims of the Society into operation in the subordinate meetings and local groups of Friends“. Daneben wurde auch die Gründung eines interracial committee beschlossen. ${ }^{17}$

15 AFSC Minutes 2/12/1924, in: AFSCA, AFSC Minutes 1924.

16 AFSC Minutes 2/12/1924, in: AFSCA, AFSC Minutes 1924.

17 AFSC Minutes 2/12/1924, in: AFSCA, AFSC Minutes 1924. 
Parallel setzten sich die Debatten um die Position des AFSC innerhalb der weiteren Society of Friends fort. Im Juli 1925 setzte Rufus Jones bei einem Treffen des AFSC in dieser Hinsicht den Ton: Was den künftigen Kurs betraf, so sei es unabdingbar, den Kontakt zu allen Teilen des Quäkertums zu erhalten. „We should not go on, unless we are sure that we have a vital mission to perform, nor unless we can speak and act for the corporate membership of the Society of Friends. " ${ }^{18}$ Hier gab es freilich noch reichlich Nachholbedarf, wie eine Denkschrift des Committee on Interpretation and Publicity, der Abteilung für Öffentlichkeitsarbeit, wenige Monate später offenlegte. Im Verhältnis mit den Quäkern in den USA stehe das AFSC vor einem philosophischen und einem finanziellen Problem, die eng miteinander verknüpft seien, hieß es hier. Eine Ermüdung der Spendenbereitschaft nach den großen Hilfsaktionen des Krieges und der unmittelbaren Nachkriegszeit sowie die schwierige wirtschaftliche Lage seien dabei nur zwei der Faktoren, welche die Arbeit des AFSC gefährdeten.

Verschärfend komme hinzu, dass das AFSC in direkte Konkurrenz zu einer Fülle von Anliegen trete, denen sich Friends in den USA gegenübersähen. QuäkerColleges, die Missionsarbeit evangelikaler Quäker, das Young Friends Movement sowie die zahlreichen Friedensgesellschaften, in denen Quäker landesweit mitwirkten - alle bemühten sich um Spenden und Unterstützung. ${ }^{19}$ Umso mehr gelte es zu berücksichtigen, dass ,the people will support the work which they believe in, which captures their imagination and which accords with their sympathy and conviction“. Genau hier befinde sich das AFSC in einer Zwickmühle zwischen message und relief work: Auf der einen Seite stünden jene, ,who do not believe we should be out to make more Quakers“ und folglich jede Art von Missionstätigkeit ablehnten. Auf dieser Seite bestünden Zweifel, ob die Arbeit in den europäischen Zentren ohne direkten Hilfsanlass nicht notwendigerweise in Missionsarbeit münden müsse, welche die Quäker als „meddlers“ erscheinen lasse. Diese Fraktion sei entsprechend „not greatly impressed with our foreign service work“ ${ }^{20}$

Auf der anderen Seite stand dagegen eine Gruppe, die ganz im Gegenteil glaubte, ,that the Service Committee's work is not sufficiently spiritual, is reformative rather than regenerative, a social service rather than a work of personal conversion, in short, an attempt to improve this world rather than to save individuals for the world to come“. Die Unterstützung dieser Gruppe zu verlieren, war

18 Memorandum des Committee on Interpretation and Publicity 1926, in: AFSCA, AFSC Minutes 1926.

19 Memorandum des Committee on Interpretation and Publicity 1926, in: AFSCA, AFSC Minutes 1926.

20 Memorandum des Committee on Interpretation and Publicity 1926, in: AFSCA, AFSC Minutes 1926. 
langfristig noch gefährlicher, weil sie die selbstgewählte Rolle des AFSC als einigende Kraft innerhalb des amerikanischen Quäkertums in Frage stellte. Der Gegensatz zwischen social gospel und personal gospel brachte vor allem die Vertreter der ersteren Ansicht in Erklärungsnot, da die vielfach in der Arbeit praktizierte ,indirect method of Christian service“ per definitionem keine greifbaren Ergebnisse zeitigte, weder was die konkreten „numbers of souls saved“ oder die Anzahl von Soldaten betraf, „who threw down their arms“, noch was die der Institutionen anging, ,who because of us have discontinued military training to date“. 21

Eine Lösung dieses Dilemmas sei nicht in Sicht, sie könne nur über eine weitere Schärfung des Quäkerprofils der Organisation erreicht werden: Es sei klar, „that a society small in numbers and limited in financial resources and enjoying a unique position in the world might do well to conserve its efforts by working more unitedly as a society“. Es gehe also darum, einerseits den gemeinsamen Nenner zu identifizieren, der die Quäker bei allen Trennlinien zusammenhielt. Andererseits sei es ratsam, sich nicht in zu viele Kooperationen mit anderen Gruppen verstricken zu lassen, ,whose whole method and philosophy differs from ours even though the ends sought may seem to agree with one or two of ours“. Dies war sicherlich auch als warnendes Signal an die Linie von Generalsekretär Wilbur Thomas zu verstehen, der auf breite gesellschaftliche Bündnisse setzte. Das Komitee schloss mit einem Katalog von Empfehlungen für die weitere Arbeit, die der Profilbildung dienlich seien: Das AFSC sollte sich dabei zuvorderst vom Vorwurf „of lacking the spiritual aspects in its work“ befreien, ohne dabei in offene Missionstätigkeit zu verfallen. Es müsse Quäker im ganzen Land davon überzeugen, dass das AFSC als „Committee of the Spirit“ ein organischer Teil des Quäkertums war, mit einer Vielzahl von „radiant centres around the world“. Auf der Basis des gemeinsamen Glaubens an „Das von Gott in jedem Menschen“ müsse das AFSC bessere und effektivere PR-Arbeit nach innen wie nach außen leisten. ${ }^{22}$ Was in dieser Debatte sichtbar wurde, war in erster Linie ein dynamischer Prozess, in dem das AFSC als expandierende und zunehmend professionelle Hilfsorganisation, seine Beziehung zum Quäkertum und der Vielfalt der religiösen Praktiken innerhalb der Society of Friends in den USA stetig neu zu bestimmen hatte.

21 Memorandum des Committee on Interpretation and Publicity 1926, in: AFSCA, AFSC Minutes 1926.

22 Es brauche nun, wie es weiter hieß, ,more imagination, clearer vision of the creative life, a deeper understanding of the creative spirit (...). AFSC must clear itself of the charge of lacking the spiritual aspects in its work. “ In: Memorandum for Committee on Interpretation and Publicity 1926, in: AFSCA, AFSC Minutes 1926. 
Dessen ungeachtet ging der organisatorische Ausbau des AFSC stetig voran. In der Zentrale übernahm die foreign service section alle verbliebene Arbeit in Übersee; parallel diente die peace section unter ihrem Leiter Ray Newton (seit 1927) als Klammer aller Aktivitäten im In- und Ausland mit im weitesten Sinn friedenspolitischem Bezug. Seine Hauptaktivität bestand in der Organisation von peace caravans und peace institutes, die sich vor allem an Jugendliche und junge Erwachsene, speziell an College-Studenten, richteten. ${ }^{23}$ Ihre Aufgabe war es, der Society of Friends zu helfen, ,to make the contribution to peace which the world, rightly, expects them to make“. ${ }^{24}$ Die Arbeit der peace section war dabei sowohl nach innen als auch nach außen gerichtet. Sie zielte darauf ab, die eine Friedensposition zu formulieren, hinter der sich alle Quäker sammeln konnten, um dann im Bündnis mit anderen einen quäkerspezifischen Beitrag zu den großen Debatten der Zeit zu leisten - etwa zu den Genfer Abrüstungsverhandlungen. ${ }^{25}$

Als weitere Abteilung entstand daneben 1927 eine interracial section. Ihre Arbeit spiegelte einen „quäkerlichen“ Ansatz im Umgang mit Rassenvorurteilen wider, dem es darum ging, durch persönliche Begegnungen Vorurteile abzubauen. „To know is to understand“, hieß es hierzu in einer Broschüre des AFSC. Die interracial section ziele in diesem Sinne darauf ab, „to present a knowledge of the Negro, the Japanese or the Indian, which will force people out of inherited fears and prejudices into a frank acknowledgment of the worth, the ability and the humanness of these peoples“. ${ }^{26}$ Fraglos war dies unter allen Sektionen diejenige, der von Seiten konservativer Quäker die größten Vorbehalte entgegenschlugen. Dies galt umso mehr, nachdem die Führung 1927 an Crystal Bird, eine afroamerikanische Frau, übertragen worden war. Birds Aufgabe war es, als Botschafterin „of her people“ $\mathrm{zu}$ fungieren. ${ }^{27}$ Wenngleich die Arbeit der interracial section bereits 1929 ihre Eigenständigkeit wieder verlor und $\mathrm{zu}$ einer Unterabteilung der peace section degradiert wurde, war auch sie doch ein Beleg für die zunehmend liberale Ausrichtung des AFSC, das sich zeitgleich den Aktivitäten von Bürgerrechtsorganisationen wie der National Association for the Advancement of Colored

23 Tenth Annual Report, in: AFSC-Bulletin 74 (1927).

24 Tenth Annual Report, in: AFSC-Bulletin 74 (1927).

25 Constructive Goodwill in Action, in: AFSC-Bulletin 74 (1927).

26 Constructive Goodwill in Action, in: AFSC-Bulletin 74 (1927).

27 „This year, Crystal Byrd, a young leader of the colored people, has come to our staff to present the life of her people to various white groups in order that we may have a deeper understanding of their problems, their progress and their needs." In: Constructive Goodwill in Action, in: AFSCBulletin 74 (1927); zur Arbeit insgesamt Negro Progress and Achievement, in: AFSC-Bulletin 75 (1927). 
People (NAACP) annäherte. ${ }^{28}$ In vieler Hinsicht überschnitt sich die Arbeit der beiden zuletzt genannten Sektionen mit jener der home service section, die für den Großteil der Aktivitäten in den USA verantwortlich zeichnete. Die Arbeit des home service war eine bunte Mischung aus Reformaktivitäten etwa in den „IndianerReservationen“ oder den social settlements der Großstädte. Summer camps und sogenannte student-in-industry-Programme, bei denen Studierende eine Zeit in Fabriken verbrachten, um den Arbeitsalltag von Industriearbeitern $\mathrm{zu}$ erleben, reflektierten die Verankerung im sozialreformerischen Milieu der meisten Mitglieder. $^{29}$

In allen Bereichen stellte die persönliche Begegnung das zentrale Element der Arbeit dar. Vor allem junge Quäker konnten und sollten ihre Zugehörigkeit zur Glaubensgemeinschaft als „fellowship of service“ erleben. Die Kontinuitäten zu den Anfängen des AFSC und seiner Idee des „constructive service“ waren allgegenwärtig. Gerade mit Blick auf junge Erwachsene wurde immer wieder der - in einem spezifisch sozial definierten Sinn - patriotische Charakter des Dienstes hervorgehoben. Ein Bericht des home service, der Ende der 1920er Jahre unter dem progammatischen Titel „Patriotic Service for young people“ erschien, ermutigte junge Menschen, „to devote at least one year of their lives to some kind of public service employment“ - in Reformschulen, Gefängnissen, „interracial schools“ und „social settlements“ oder bei Wiederaufforstungsmaßnahmen. Dieser Dienst wurde erneut in Anlehnung an William James als „moral equivalent to war“ bezeichnet, als Krieg gegen Armut und Vorurteil, der die „Rekruten“ mit „healthier sympathies and soberer ideas“ über die grundlegenden sozialen Problemen in den USA ausstatte, mit denen sie in ihre vertraute Umgebung, in ihr Studium oder auf ihren beruflichen Weg zurückkehrten. ${ }^{30}$ Dieses Motiv des home service - als

28 „The Quaker is the traditional friend of the Negro“, heißt es hierzu in Sylvester Jones' früher Geschichte des AFSC. Für Jones schienen die Aktivitäten der interracial section als logische Fortführung einer 150 Jahre zurückreichenden Tradition. Jones, Quakers in Action: Recent Humanitarian and Reform Activities of the American Quakers., 197-200.In den 1930er Jahren wurde der Interracial activism des AFSC zum Ausgangspunkt einer längerfristigen Verbindung der Quäker mit der afroamerikanischen Bürgerrechtsbewegung. Die Karriere von Bayard Rustin, einem der Mitverfasser der einflussreichen pazifistischen AFSC-Streitschrift „Speak Truth to Power“ (1955), Organisator des Marsches auf Washington 1963 und enger Vertrauter Martin Luther Kings begann in einem Seminar des AFSC 1937. Zu Rustin siehe Buzz Haughton, „Bayard Rustin: An Annotated Bibliography of Materials Relating to Rustin as a Quaker.“ Quaker Studies 4, no. 1 (1999): 55-67. Allgemein zum interracial work des AFSC Allan W. Austin, Quaker Brotherhood: Interracial Activism and the American Friends Service Committee, 1917-1950 (Urbana: University of Illinois Press, 2012).

29 Students in Industry, in: AFSC-Bulletin 72 (1927).

30 Patriotic Service for Young People, in: AFSC-Bulletin 71 (1927). 
Ausdruck eines dezidiert patriotisch porträtierten sozialen Dienstes an der Allgemeinheit, der gleichsam als Initiationsritus für junge Quäker diente - wurde in der Folge immer wieder aufgegriffen. „Patriotism is everywhere finding new forms of expression. Our national heroes have come to be those who are helping to build a world where men can have more abundant life (...).“ Quäker durften dabei nicht abseits stehen: „Friends are obligated to render positive service rather than maintain a merely negative testimony“ - zu Hause und in der Welt. ${ }^{31}$ Hier ähnelten die Begründungen für einen sozialen Aktivismus im Übrigen insofern denen für den unbedingten Pazifismus des AFSC, als beide sich auf die Idee eines „konstruktiven Patriotismus“ stützten. In Wilbur Thomas’ Worten waren die Quäker „patriotic and loyal, not to the wrong, but to the right“. Sie sähen Menschen aller Rassen und Glaubensrichtungen als ihre Mitmenschen an: „Love of country does not imply hatred of enemies. The flag is loved not because it excludes, but because it draws to higher and better things. “32

Ende der 1920er Jahre kam damit der Konsolidierungsprozess des AFSC zu einem vorläufigen Ende. Zu diesem Zeitpunkt arbeiteten in der Zentrale des AFSC in Philadelphia rund siebzig Mitarbeiter. Gleichzeitig baute das AFSC seine regionalen Strukturen in den USA aus. Es entstanden branch offices in Boston, Pasadena und Richmond, Indiana, Letzteres als Zentrum für Quäker aus dem Mittleren Westen, deren Leiter, Murray Kenworthy, als vormaliger Leiter der AFSCMission in der Sowjetunion, die Verbindung zwischen home und foreign service verkörperte. Die regionale Erweiterung war dabei nur eine der Methoden, durch die das AFSC seine Präsenz im Leben der Society of Friends zu stärken hoffte. Dies geschah zur selben Zeit, in der das AFSC im Zeichen der Professionalisierung mehr und mehr Mitarbeiter rekrutierte, die keine Quäker waren. ${ }^{33}$

Wie prekär das Gleichgewicht war zwischen dem sozial profilierten Aktivismus des Komitees auf der einen Seite und andererseits dem Anspruch, als Vertreter der Society of Friends in all ihrer Vielfalt aufzutreten, zeigte sich freilich nach wie vor an vielen Stellen. Deutlich hervor trat dies etwa in Form des Plans zur Reorganisation des AFSC, auf die sich die Vertreter der unterschiedlichen Richtungen im März 1929 einigten. Als Hauptaufgabe betonte der Plan - neben der ,provision for young people of opportunities for voluntary public service in constructive enterprises“ - insbesondere die Rolle des AFSC als Kanal der Zusammenarbeit zwischen den unterschiedlichen Strömungen des Quäkertums in den USA. Während es grundsätzlich um „deeper fellowship among friends“ ging,

31 Home Service Bulletin, in: AFSC-Bulletin 82 (1929).

32 The Biblical Basis of Friends Opposition to War, in: AFSC-Bulletin 77 (1928).

33 Barnes, A Centennial History of the American Friends Service Committee, 62-70. 
versicherte das Papier zur selben Zeit, dass das AFSC keinesfalls in Konkurrenz zu den existierenden religiösen Strukturen der Society of Friends zu treten beanspruche, sondern nur in enger Absprache und beschränkt auf einen klar abgegrenzten Handlungsbereich tätig werden wolle. ${ }^{34}$

Auch der Kritik an der aus Sicht vieler Quäker zu weltlichen Orientierung des AFSC begegneten die Autoren des Plans. Als Hauptziel aller Aktivitäten in und außerhalb der USA wurde die Verbreitung des „Christian ideal of goodwill and understanding as the preventive and corrective of strife between economic racial and national groups“ ausgewiesen. Das AFSC war und blieb, so die Botschaft, eine fest im christlichen Glauben verankerte Vereinigung. Dies galt auch oder gerade in der Zusammenarbeit mit anderen Organisationen ohne Verbindung zur Society of Friends (,similar organisations outside the society“). Solche Kooperationen waren ausdrücklich erwünscht, doch sollte dabei eine Prämisse gelten: „always making the distinctive religious basis evident behind our activity“. ${ }^{35}$

Damit reflektierte der Plan die Konflikte, die den Ausbau des Komitees und seinen Wandel zu einer permanenten Organisation begleitet hatten und die auch gegen Ende der 1920er Jahre (noch) weiter schwelten. In den vorangegangenen Monaten hatte sich die Unzufriedenheit unter konservativeren Mitgliedern des AFSC mit dem Kurs und vor allem der Bündnispolitik Wilbur Thomas' sogar noch verschärft und schließlich hatte sie dazu geführt, dass der Generalsekretär Anfang 1929 seinen Posten nach rund zehn Jahren räumen musste. Einen von mehreren Auslösern stellte der Präsidentschaftswahlkampf 1928 dar, in dem Herbert Hoover für die Republikaner gegen den linken Demokraten Al Smith antrat und in dem die Führungsfiguren im AFSC auf unterschiedlichen Seiten standen. Aus Sicht von Jones wurden die langanhaltenden Animositäten zwischen Thomas und Hoover, die mindestens bis in die Zeit des russischen Hilfseinsatzes zurückreichten, nun zu einem Problem für das AFSC. 1926 war Thomas in Verdacht geraten, Hoover belastendes Material aus dem Kontext der Zusammenarbeit in Russland an die Presse geliefert zu haben. Einige Mitglieder des Komitees hatten dies zum Anlass genommen, seine Führung einer internen Untersuchung zu unterziehen - ein innerhalb der auf Konsens beruhenden Organisationskultur des AFSC präzedenzloser Schritt. Im Sommer 1928 veröffentlichte Rufus Jones unter eigenem Namen, aber auf Briefpapier des AFSC, eine Unterstützungserklärung zugunsten von Hoovers Präsidentschaftskandidatur. In der Kopie, die er an Thomas weiterleitete, fand sich der handschriftliche Vermerk: „Wilbur, we had to get this letter out to offset your nefarious propaganda against Hoover!“ Nach Hoovers Sieg

34 The Reorganization Plan in Brief, in: AFSC-Bulletin 81 (1929).

35 The Reorganization Plan in Brief, in: AFSC-Bulletin 81 (1929). 
im November desselben Jahres ging der Konflikt in die letzte Runde. Im anhaltenden Streit um die generelle Ausrichtung des Komitees düpierte Jones den Generalsekretär, indem er an Thomas vorbei einen Brandbrief veröffentlichte, in dem er erneut forderte, das AFSC ,in line with the needs of the Society“ zu bringen. Dies war nicht weiter außergewöhnlich, wohl aber der Vermerk, dass, wenn dies nicht gelänge, ein möglicher nächster Schritt darin bestehen müsse, „to suspend its work and mission until a new crisis may call it again into being“. Thomas reagierte auf diese Herausforderung seiner Autorität, indem er schließlich im Februar 1929 seinen Rücktritt einreichte. ${ }^{36}$

\section{Von Hoover zum New Deal}

Als Nachfolger wurde Clarence Pickett bestimmt, wie Thomas ein Quäker aus dem Mittleren Westen. Pickett, der einige Jahre Bibelkunde am Quäker-College Earlham in Richmond, Indiana, unterrichtet hatte, war 1921 zum Leiter des zu diesem Zeitpunkt neu eingerichteten home service des AFSC berufen worden, was seinerzeit auch als eine Geste an evangelikale und konservativere Friends zu verstehen gewesen war. Wenngleich Pickett in seiner Jugend der Missionsbewegung nahegestanden hatte, vertrat er theologisch und politisch moderat liberale Positionen und war nach Guy Aiken ein Kandidat, der für alle Seiten akzeptabel war. ${ }^{37}$ Seine Wahl zum Executive Secretary war fraglos ein politisches Signal, dass sich das AFSC noch stärker auf die Festigung der Quäkeridentität und die Verankerung des Komitees innerhalb aller Branchen der Society of Friends in den USA konzentrieren wolle. Gleichzeitig war Pickett durch seine Arbeit im home service gerade mit jenen Unternehmungen verknüpft, die das progressive Bild der Organisation nach außen prägten. ${ }^{38}$

Der Beginn der Weltwirtschaftskrise im Herbst des Jahres 1929 und die einsetzende Great Depression machte dann die meisten Planungen obsolet. Pickett blieb nur wenig Zeit, sich in das Amt des Generalsekretärs einzuarbeiten (das er nahezu 20 Jahre, bis 1947, innehaben sollte). Eine erste Bewährungsprobe mit Signalwirkung hatte er jedoch bereits zuvor zu überstehen. Wie rund zehn Jahre zuvor für Wilbur Thomas, so war der Anlass auch diesmal ein industrieller Kon-

36 Barnes, A Centennial History of the American Friends Service Committee, 71-73.

37 Aiken, Social Christianity, 103-104.

38 Lawrence McK. Miller, Witness for Humanity. A Biography of Clarence E. Pickett (Wallingford, PA: Pendle Hill Publications, 1999); Siehe auch die Autobiographie Clarence Evan Pickett, For More Than Bread: An Autobiographical Account of Twenty-Two Years' Work with the American Friends Service Committee (Boston: Little, 1953). 
flikt im eigenen Land. In diesem Fall waren es keine Bergleute, sondern die Arbeiter in der Textilindustrie North Carolinas, die das AFSC und seinen neuen Generalsekretär zwangen, Position zu beziehen. In der Stadt Marion waren im Frühjahr 1929 die Belegschaften der dortigen Fabriken für bessere Arbeitsbedingungen in den Streik getreten. Auch in diesem Fall reagierten die Fabrikbesitzer mit Härte. Die Initiative einer Hilfsaktion für die Arbeiter und ihre Familien kam von gewerkschaftlichen Aktivisten mit Verbindungen zum AFSC. Insbesondere der Sozialist Abraham Johannes (A.J.) Muste, ein Quäker aus Rhode Island und eine spätere Ikone der amerikanischen Friedens- und Bürgerrechtsbewegung ${ }^{39}$, und James Myers, ein Presbyterianer, der das Industrial Department des liberalprotestantischen Federal Council of Churches (FCC) leitete, spielten eine herausragende Rolle. ${ }^{40}$ Ohne direkten Zugang zum Schauplatz des Konflikts (der ihnen von den Besitzern der Fabriken verwehrt wurde) traten sie an das AFSC mit der Bitte heran, nach dem Vorbild der Hilfe für die Bergleute sechs Jahre zuvor eine Hilfsaktion zugunsten der notleidenden Familien der streikenden Arbeiter zu leiten. ${ }^{41}$

Nach kurzer Diskussion willigte das AFSC ein und entsandte einen Vertreter nach Marion, der mit den Industriebossen ein Abkommen aushandelte, das es den Quäkern ermöglichte, unter dem Versprechen strikter Neutralität eine Hilfsaktion für die Familien der Arbeiter durchzuführen. Dieser Anspruch war freilich nicht weniger prekär als in den Kohlegruben zu Anfang der 1920er Jahren. Das Geld für die Hilfsaktion kam zum großen Teil von Seiten der Unterstützer des Streiks. Diese bedienten sich des AFSC als Kanal für ihre Gelder und sahen die Quäker dabei als Verbündete, ganz ähnlich den pro-sowjetischen Gruppen während der russischen Hilfsoperation. Während sich die Quäkerhelfer von Seiten der Fabrikbesitzer dem Verdacht ausgesetzt sahen, auf der Seite der Streikenden zu stehen, trieben sie in den Augen von Aktivisten wie Myers und Muste ganz im Gegenteil ihre neutrale Position oftmals zu weit. Das Elend der Streikenden und ihrer Familien lindern zu wollen, ohne gleichzeitig deren Sache gegenüber den Verantwortlichen für diese Misere, sprich: den Fabrikbesitzern, zu vertreten, erschien den Aktivisten widersinnig. Immer wieder kam es zu Auseinandersetzungen in dieser Frage.

39 Leilah Danielson, American Gandhi: A. J. Muste and the History of Radicalism in the Twentieth Century, Politics and Culture in Modern America (Philadelphia: University of Pennsylvania Press, 2014). Cook, Spiritual Socialists : Religion and the American Left.

40 Elizabeth Fones-Wolf/Ken Fones-Wolf, „Lending a Hand to Labor: James Myers and the Federal Council of Churches“, 1926-1947, in: Church Hisotry 68, 1 (1999), 62-86.

41 The Marion Work, in: AFSC Annual Report 1930, 12. : Siehe auch Aiken, „Social Christianity,“ 137. 
Clarence Pickett insistierte dabei, das AFSC könne seine Aufgabe innerhalb des bestehenden Konflikts nur dann zum Wohle der Notleidenden ausüben, wenn es sich blind gegenüber der Existenz von Konfliktparteien stelle. Zweifellos war auch diese Konstruktion eines konflikt- und mithin politikfreien „humanitarian space“ - ante litteram - nicht zuletzt von den Erfahrungen der Russlandhilfe inspiriert. Was kaum ignoriert werden konnte, war hingegen, dass Neutralität unter den Bedingungen einer asymmetrischen Konfliktsituation wie im vorliegenden Arbeitskonflikt im Kern einer Parteinahme zugunsten der schwächeren Seite gleichkam. Bei aller zur Schau getragenen Unparteilichkeit stärkte die Hilfe des AFSC die Position der Streikenden, was der wesentliche Grund dafür war, warum pro-labor-Aktivisten wie Muste oder Myers ihren gelegentlichen Unmut niemals in offenen Streit eskalieren ließen.

1930 zog der Jahresbericht des AFSC eine in jeder Hinsicht positive Bilanz des Einsatzes und betonte dabei bewusst religiöse und soziale Aspekte: „During these four months“, so hieß es hier, „the spirit in Marion was very greatly improved.“

The hatred, bitterness, fear, and suspicion, amounting to a state of civil war, which we found at the outset, have greatly diminished. The church people and business men are more sympathetic to the strikers; (...) wages and hours are somewhat better; and many of the strikers, who had dropped away from their churches (or been excluded for union membership) have again laid hold of their faith in God and man. ${ }^{42}$

Für Pickett war Marion eine wichtige Erfahrung, deren Lehren noch in künftigen Einsätzen nachhallten (wie etwa im Fall des Spanischen Bürgerkriegs zu zeigen sein wird). Im Rückblick erhöhte die Beteiligung an einem weiteren Arbeitskonflikt in den USA trotz aller fortbestehenden Einwände die Akzeptanz für solche Einsätze und bereitete den Boden für eine ganze Reihe weiterer Aktionen in den folgenden Jahren. Die Weltwirtschaftskrise, die sich parallel zum Einsatz mit voller Wucht bemerkbar zu machen begann, zu Massenarbeitslosigkeit führte und Millionen von Menschen in unmittelbare Not stürzte, tat dabei ein Übriges.

Anfänglich kaum erkennbar, führte die Erfahrung der Great Depression nach und nach zu einer weiteren Neupositionierung des AFSC: Sie brachte das Komitee erstmals in den Orbit staatlicher Krisenpolitik. Hier war das AFSC in den Kohlegebieten der südlichen Appalachen 1931 erneut gefragt, in einem industriellen Konflikt tätig zu werden. Hintergrund war erneut ein Streik von Kohlegrubenarbeitern, der sich mit der ohnedies herrschenden wirtschaftlichen Misere zu einer explosiven Gemengelage vermischte. Wenngleich sich diese Aktion praktisch direkt an die in Marion anschloss, waren die Voraussetzungen dieses Einsatzes ganz

42 AFSC Annual Report 1930, 12. 
andere, denn diesmal kam der ursprüngliche Aufruf zur Hilfe nicht aus den Kreisen gewerkschaftlicher und politischer Unterstützer der Streikenden, sondern von oben, aus dem Weißen Haus. Es war Präsident Herbert Hoover selbst, der Grace Abbott, die Leiterin der staatlichen Behörde für Kinderschutz (US Children's Bureau), mit dem Auftrag zu Rufus Jones schickte, das AFSC um Mithilfe zu bitten. Zuvor hatte das Amerikanische Rote Kreuz, das seit Beginn der Weltwirtschaftskrise verstärkt Hilfsaktionen in den USA durchführte, sein Zögern signalisiert, in einem politisch so aufgeladenen Konflikt tätig zu werden. Aus Hoovers Sicht waren die Quäker daher ein logischer Ansprechpartner, ganz ungeachtet aller vorangegangenen Differenzen. In Philadelphia hatte der home service Anfang 1930 ein Speisungsprogramm für 10.000 Kinder organisiert sowie ein kleineres Arbeitsbeschaffungsprogramm, das rund 700 Familien für kurze Zeit ein Einkommen sicherte. Daran knüpfte Hoover an. Nach Treffen mit Abbott und Fred Croxton, dem Vorsitzenden des Emergency Committee for Employment des Präsidenten, sowie schließlich mit Hoover selbst im Weißen Haus, beschloss das AFSC im Mai 1931, das Angebot anzunehmen. Wie in Europa sollte sich das AFSC bei seinem Einsatz in erster Linie um die Speisung von Kindern kümmern. Für den Einsatz bot Hoover den Quäkern Restmittel des European Children's Fund an, was die Verbindung zum foreign relief der Vergangenheit nur umso deutlicher machte. ${ }^{43}$

Damit war eine Grundlage geschaffen, auf der das AFSC von 1931 bis 1934 in sechs Bundesstaaten von Maryland bis nach Tennessee Zehntausende von täglichen Mahlzeiten an die Kinder der Bergarbeiter, an Schwangere und stillende Mütter verteilte. Wie in Deutschland zehn Jahre zuvor fanden die Speisungen an Schulen und unter Beteiligung einer Vielzahl von lokalen Helfern statt. Ein gewichtiger Unterschied bestand jedoch darin, dass in den Appalachen in weitaus höherem Umfang als jemals zuvor neben die Maßnahmen zur unmittelbaren Behebung der Not längerfristige Überlegungen zur rehabilitation der rund 200.000 arbeitslosen Bergarbeiter und ihrer Familien traten. ${ }^{44}$ Der Trend gehe, wie ein Bericht zur Arbeit in den Kohlegebieten von 1934 vermerkte „toward educational and social reconstruction rather than toward relief.“ ${ }^{45}$ Anknüpfungspunkte lieferte neben den Erfahrungen, die das AFSC in Frankreich während des Ersten Weltkriegs beim Wiederaufbau zerstörter Frontdörfer erworben hatte, vor allem der home service, in dem längerfristige Projekte seit geraumer Zeit erprobt worden

43 Hoover verpflichtete sich anfänglich zu einer Übertragung von \$225,000 an das AFSC, die das Komitee am Ende aus eigenen Mitteln um den selben Betrag ergänzen musste. Aiken, Social Christianity, 154.

44 Service and Relief in the Bituminous Coal Areas, in: AFSC Annual Report 1933, 16-17.

45 Education stressed, in AFSC Annual Report 1934, 14. 
waren. Rehabilitation bedeutete zunächst konkret, den Bergarbeitern über berufsbildende Maßnahmen eine Perspektive zu verschaffen. Er beinhaltete darüber hinaus jedoch auch die Ansiedlung von Arbeiterfamilien in neu gegründeten homesteads, in Modellsiedlungen, hinter denen eine umfassende, an Ideen des social engineering geschulte Vision stand. Einige der zugrunde liegenden Ideen fasste ein AFSC-Memorandum 1934 zusammen: Der ganzheitliche Ansatz sah neben vielen weiteren Maßnahmen unter anderem die Einrichtung von Kliniken und Kooperativen, von Institutionen der Berufsausbildung sowie allgemeine Lebensberatung vor, außerdem den Aufbau von Büchereien ebenso wie von gemeinschaftlichen Selbstversorgungseinrichtungen wie Gärten und Großküchen. ${ }^{46}$ Homesteads wie das 1933 gegründete Arthurdale dienten damit als Hebel, „to educate and reorient the community of miner families and set them into action“. ${ }^{47}$

Damit entfernte sich das AFSC beträchtlich von dem Ansatz der Anfangszeit, der sich nur auf die Nothilfe konzentriert hatte. Gleichzeitig blieb von dem noch wenige Jahre zuvor gehegten Anspruch, message work im Sinne einer Integration der Society of Friends in den USA zu leisten, zumindest äußerlich kaum etwas übrig. Die neue Vision des AFSC war politisch und sozial. Auch in den USA selbst trat das Komitee immer mehr als eine professionelle Hilfsagentur mit weltlicher Zielsetzung auf. So signalisierte dieser Übergang zu langfristig angelegten Hilfsmaßnahmen vor dem Hintergrund der Weltwirtschaftskrise, der seinen Ausdruck auch in der Gründung einer social-industrial section im Juni 1935 fand $^{48}$, einen tiefgreifenden und nachhaltigen Wandel. Er eröffnete dem home service des AFSC eine dauerhafte Perspektive, verlieh dem Komitee Sichtbarkeit und verschaffte neue Möglichkeiten auf anderer Ebene, um die eigene Identität zu stärken. Und mehr als das: Nach Jahrzehnten, in denen die Quäker, bestärkt durch die leidvollen Erfahrungen des Ersten Weltkriegs, auf Distanz zu staatlichen Stellen geblieben waren, handelten sie unter Hoovers Präsidentschaft erstmals im direkten staatlichen Auftrag. Dieser Übergang war schleichend, nicht zuletzt da sich die Zusammenarbeit mit Hoover in dessen voluntaristischen Ansatz des emergency relief einfügte, bei dem privater Initiative eine zentrale Rolle zukam. Dennoch veränderte sich durch diese Zusammenarbeit die Perspektive des AFSC nachhaltig: War der constructive service der Quäker zuvor vorwiegend defensiv ausgerichtet gewesen - entworfen, um dem Vorwurf mangelnden Patriotismus zu entgehen -, so wurde daraus nun ein Dienst, der im positiven Sinne eine Annä-

46 Barnes, A Centennial History of the American Friends Service Committee, 85 - 92.

471933 hatte die Regierung ein großes Stück Land in Reedsville, West Virginia, erworben und dem AFSC zur Gründung einer homestead community für Hunderte von Bergarbeiterfamilien überlassen. Die Familien erhielten jeweils ein Stück Land, um ihre eigenen Häuser zu bauen. 48 The social-industrial section, in: AFSC Annual Report 1935, 7. 
herung an den interventionistischen Staat im Inneren implizierte. Dabei waren die Quäker nicht allein. Viele der christlichen Kirchen in den USA vollzogen während der Great Depression einen Gesinnungswandel, was die Zusammenarbeit mit und die Rolle des Staates allgemein bei der Bekämpfung sozialer Notlagen betraf. Für das AFSC waren die Folgen so weitreichend, wie wenige im Komitee dies gegen Ende der 1920er Jahre für möglich gehalten hatten. Doch dies war erst der Anfang. Angesichts der politischen Nähe vieler AFSC-Mitglieder zu Hoover war es nicht ohne Ironie, dass die Annäherung des AFSC an den Staat ihre volle Blüte erst unter dessen Nachfolger Franklin Delano Roosevelt erreichen sollte. ${ }^{49}$

Es waren insbesondere die homesteads, die den Schlüssel bereithielten, der es dem AFSC erlaubte, nach Roosevelts Wahl im November 1932 in eine neue Phase der Expansion einzutreten. ${ }^{50}$ Die sozialtransformativen Effekte, die diese Siedlungen in den Kohlegebieten West-Virginias, Ohios und Kentuckys zu zeitigen versprachen, fügten sich in Roosevelts Ideen eines New Deal für die von der Wirtschaftskrise besonders hart getroffenen Gebiete nahtlos ein. Die homesteads firmierten als Teil der im Rahmen des 100-Tage-Programms des neuen Präsidenten eingerichteten Federal Emergency Relief Administration (FERA). Bei der Senatsanhörung im August, die der Einrichtung der Behörde voranging, trat Clarence Pickett als einer der Zeugen auf. Kurze Zeit später bot Innenminister Harold Ickes Pickett die Leitung der Abteilung für Stranded Mining and Industrial Populations an, die zur neugegründeten Subsistence Homestead Division im Ministerium gehörte. Sie war als Teil des National Industrial Recovery Act gegründet worden. Pickett übergab in der Folge Teile seiner Aufgaben als Generalsekretär des AFSC an Elizabeth Marsh und verbrachte drei bis vier Tage in der Woche auf seinem Washingtoner Posten. ${ }^{51}$

Ausgestattet mit einem eigenen Budget, begann das AFSC weitere homesteads zu errichten und die vorhandenen auszubauen. Als bekannteste Siedlung wurde Arthurdale in West-Virginia ausgebaut, die weithin als Leuchtturmprojekt der homestead-Bewegung galt. Ab 1937 bis 1943 sollte mit Penn-Craft südlich von

49 Aiken, „Social Christianity,“ 152-186. Zum größeren Kontext siehe Andrew J. F. Morris, The Limits of Voluntarism: Charity and Welfare from the New Deal through the Great Society (Cambridge/New York: Cambridge University Press, 2009); Jarod Roll and Erik Gellman, The Gospel of the Working Class: Labor's Southern Prophets in New Deal America (Urbana and Chicago: University of Illinois Press, 2011).

50 Aiken, „Social Christianity,“ 152-186; Jerry Bruce Thomas, An Appalachian New Deal: West Virginia in the Great Depression (Morgantown: West Virginia University Press, 2010); Jack Sutters, American Friends Service Committee, Philadelphia (New York/London: Garland, 1990).

51 Miller, Witness for Humanity: A Biography of Clarence E. Pickett. 
Pittsburgh noch ein weitere weithin beachtete Modellsiedlung entstehen. ${ }^{52}$ Der Aufbau von Arthurdale führte darüber hinaus noch in weiterer Hinsicht zur Integration des AFSC in den New Deal. Im November 1933 arrangierte Clarence Pickett für die First Lady Eleanor Roosevelt eine Tour, die den Beginn einer langen Zusammenarbeit darstellte. Eleanor Roosevelts Einfluss verdankten Pickett und das AFSC über viele Jahre hinweg direkten Zugang zum Weißen Haus. Das AFSC war damit quasi offizieller Teil der Roosevelt-Administration und ein „federal arm of the New Deal“ geworden. ${ }^{53}$ Dieser Schwenk sollte auch für die internationale Arbeit des AFSC nicht ohne Folgen bleiben, wie die folgenden Kapitel zu Deutschland nach 1933 und zum Spanischen Bürgerkrieg zeigen werden.

\section{Die internationale Arbeit nach den Hilfseinsätzen}

Angesichts des massiven Bedeutungsgewinns der Arbeit in den USA geriet die internationale Arbeit fast zwangsläufig in den Hintergrund. Zu Anfang der 1930er Jahre waren die Hilfseinsätze nach dem Ersten Weltkrieg für viele eine ferne Erinnerung, die in der täglichen Arbeit des AFSC kaum eine Rolle spielte. Dabei waren die Spuren der Hilfsaktionen noch allgegenwärtig. Sie lebten weiter in den Verbindungen mit Hoover ebenso wie in der Praxis der Hilfe zu Hause, die auf vielerlei Weise von den Erfahrungen jener Hilfseinsätze geprägt war. Auch bestanden enge personelle Kontinuitäten. Bereits beim ersten Einsatz des AFSC in den Kohlefeldern in den frühen 1920er Jahren hatte das Komitee mit Drew Pearson (dem späteren Starjournalisten) einen Mann beauftragt, eine Bestandsaufnahme vorzunehmen, der gerade von einem Einsatz gemeinsam mit den britischen Quäkern aus Serbien zurückgekehrt war. Ihm folgten eine ganze Reihe von Veteraninnen und Veteranen der deutschen, polnischen und insbesondere der russischen Hilfsaktionen, die in der Arbeit des Komitees in den USA prominent vertreten waren und für eine Reihe von „Little Russias“ in den Appalachen standen. Murray Kenworthy als Chef der Richmond branch des AFSC war nur einer davon. Homer Morris, ein weiterer Veteran der Russlandhilfe, wurde 1931 zum Direktor der neugegründeten Coal Relief Section im Hauptquartier, als seine Stellvertreterin diente die ehemalige Ko-Leiterin des Moskauer Büros, Anna Haines. Alice Davis, eine der letzten Vertreterinnen des AFSC in Moskau, war Distriktleiterin für West-Virginia (wo das besonders umkämpfte Harlan County lag)

52 Die Entwicklung von Penn-Craft findet sich in den Jahresberichten breit abgebildet: Von den umfangreichen Vorplanungen in AFSC Annual Report 1937, 7-12 bis hin zur Fertigstellung im Krieg AFSC Annual Report 1943, $16-17$.

53 Aiken, „Social Christianity.“, 178. 
und leitete für einige Zeit das Hilfsprogramm in Arthurdale. Aber auch Alfred Scattergood, Caroline Norment oder Carolena Wood blieben dem AFSC treu und stellten eine Verbindungslinie zu den großen Hilfsaktionen der Vergangenheit dar.

Im Gegensatz dazu spielten die Auslandsaktivitäten selbst bald nur noch eine Nebenrolle. Beim Aufbau des home service war anfänglich noch über eine Ausdehnung der Aktivitäten auf die Nachbarstaaten der USA debattiert worden. Namentlich Kanada, Mexiko und die Karibik, aber auch entferntere Ziele wie China und Japan waren angedacht, um dann im Laufe der 1920er Jahre langsam in den Hintergrund zu treten. Über das Friends Mission Board organisierte das AFSC noch eine kleinere Hilfsaktion anlässlich des Großen Kantō-Erdbebens in Tokio im September 1923. Dabei blieb es jedoch, wenngleich die japanisch-amerikanischen Beziehungen und die Auseinandersetzung mit den verschärften und vor allem gegenüber asiatischen Einwanderern diskriminierenden Immigrationsgesetzen der frühen 1920er Jahre ein Schwerpunkt in der Arbeit vor allem der peace section und der interracial section blieben. ${ }^{54}$ China, ein klassisches Zielgebiet amerikanischer Missionare blieb dagegen lange außerhalb des Radars des AFSC. Erst die Einrichtung eines Far East Committee 1932 signalisierte einen ersten Wechsel. Sie geschah vor dem Hintergrund der verschlechterten japanisch-chinesischen Beziehungen, als „evidence of the concern of Friends through the American Friends Service Committee with regard to the war activities between China and Japan and the Manchurian affair" und wurde zum Auftakt einer langsamen Neuausrichtung, die Ende der 1930er Jahre klarere Konturen annahm. ${ }^{55}$ Das AFSC beteiligte sich auch an den Diskussionen um Gegenwart und Zukunft der Kolonien. Wenngleich diese Frage im Vergleich zu Großbritannien weitaus weniger Raum einnahm, beobachtete das AFSC diese Debatten aufmerksam und beteiligte sich an der Organisation von Vortragsreisen von Persönlichkeiten der indischen Unabhängigkeitsbewegung, die den Quäkern verbunden waren, wie Mohandas Gandhi oder des Poeten Rabindranath Tagore. Zwei amerikanische Quäker, das Ehepaar

54 Gegen den Alien Immigration Act von 1924 nahm das AFSC wiederholt dezidiert Stellung. So hiess es hierzu im Jahresbericht von 1925: „As soon as it was discovered that Alien Immigration Act was not to keep the American labor market from being flooded with cheap labor or to prevent America from being overrun with peoples form another country, but an act of race discrimination as far as the Orientals were concerned, the Interracial Section undertook to acquaint the American public with these facts and thus to counteract as much as possible the bad influences of the act." In AFSC Annual Report 1925, 10; Dieses Statement setzte den Ton für eine Vielzahl von Aktionen, die speziell auf Japan und die japanische Einwanderung gerichtet waren. Siehe etwa exemplarisch: Message to the American People on Japan, in: AFSC-Bulletin 73 (1927).

55 AFSC Annual Report 1932, 13. 
Harry und Rebecca Timbres, unternahmen ab 1929 im Namen AFSC an Sozialarbeit in Tagores Ashram im westbengalischen Shantiniketan. ${ }^{56}$ Erhalten blieb schließlich auch eine Präsenz im Nahen Osten die in ihren Ursprüngen auf die Einrichtung einer Quäkerschule im palästinensischen Ramallah im Jahr 1889 zurückging. Nach dem Ersten Weltkrieg hatte die ursprüngliche Quäkermission (unter der Aufsicht des American Friends Board of Foreign Missions) zwar einen deutlich humanitären Charakter angenommen. Zur selben Zeit half das Engagement in Palästina auch die Verbindung zwischen dem AFSC und evangelikalen Friends zu stärken. ${ }^{57}$

Der Schwerpunkt der internationalen Arbeit blieb auch nach dem Ende der großen Hilfseinsätze Europa. Abgesehen von einigen kleineren Programmen der britischen Kollegen in Bulgarien und Griechenland, ${ }^{58}$ an denen sich das AFSC beteiligte, galt die ganze Aufmerksamkeit der foreign service section hier der Arbeit in den sogenannten „Quäkerbotschaften“. Die ursprüngliche Initiative für solche Einrichtungen ging wie zuvor beschrieben auf den radikalpazifistischen Kreis britischer Quäker um Carl Heath zurück, der Mitte der 1920er Jahre die Führungsrolle in der internationalen Arbeit in London innehatte. Heath hatte nach dem Krieg für die Errichtung von Quäkerbotschaften plädiert. Sie sollten das Mittel sein, mit dem britische und US-amerikanische Quäker die begonnene Versöhnungsarbeit gemeinsam mit Gleichgesinnten in den jeweiligen Zielländern betreiben konnten. Solche Zentren entstanden ab 1920 nacheinander in Berlin, Wien, Paris, Warschau und Moskau und an einigen anderen Orten (in Deutschland etwa in Frankfurt am Main und Nürnberg). ${ }^{59}$ Aus amerikanischer Sicht drückte sich in diesen Zentren - wie im Fall Deutschlands gezeigt wurde: nach anfänglicher Skepsis - das Bekenntnis und gleichzeitig das Versprechen an die britischen Quäker aus, nach den weitgehend entlang nationaler Linien getrennten Hilfsmissionen in Deutschland und Russland am Aufbau eines grenzübergreifenden Quäkerwerks zu arbeiten. In ihnen fand der Anspruch Ausdruck, wie es im

56 Ab 1928 tauchte Indien regelmäßig in den Jahresberichten des AFSC auf, sowohl mit Bezug auf Gandhi und die indische Unabhängigkeitsbewegung als auch über die Arbeit der Timbres. AFSC Annual Report 1928, 7; Zur Beziehung der britischen Quäker zu Indien und dem indischen Freiheitskampf siehe die Biografie des Gandhi-Vertrauten Horace Alexander, Geoffrey Carnall, Gandhi's Interpreter: A Life of Horace Alexander. Edinburgh: Edinburgh University Press, 2010.

57 Siehe Frost, „Our Deeds Carry Our Message“, 41; Ausführlicher siehe Maria Carter Hallward, „The Ramallah Friends Meeting: Examining One Hundred Years of Peace and Justice Work“ Quaker Studies 13, 1 (2013).

58 Barnes, A Centennial History of the American Friends Service Committee, 58-59.

59 Quaker Embassies. A Survey of Friends Service in Europe since 1919 (London: Friends House, 1933). 
bereits zitierten Strategiepapier von 1926 hieß, ,to visualize the whole society (of Friends) as a ,Committee of the Spirit“ with radiant centres around the world“. ${ }^{60}$

Über die hohen Erwartungen, die sich an solche „International Centers of Goodwill“ knüpften, geben verschiedene Broschüren des AFSC aus den 1920er Jahren Auskunft. Ihr Hauptzweck und grundsätzlicher Ansatz bestand darin, einen Raum zu schaffen, in dem nationale Vorurteile über persönliche Begegnungen abgebaut würden. Ein Bericht aus dem Jahr 1924 veranschaulichte dies:

(I)n each of the countries (...) one or more capable people are placed in charge of the centre. They secure a suit of rooms which can be used for conference or meeting room, reading room, writing room, social room etc. The person in charge endeavours to get in touch with the native people who are most active in humanitarian, social or religious work. The conference room is used for meetings where such problems as immigration, public health, criminology, the League of Nations, the World Court, the Labour movement, international trade et cetera are discussed. ${ }^{61}$

Der Auswahl der Mitarbeiter in diesen Zentren kam folglich große Bedeutung zu, sowohl was ihre Persönlichkeit als auch was ihren intellektuellen Hintergrund betraf; das Ziel war, wie es weiter hieß, „to make each one of its workers in every country a centre of goodwill““. ${ }^{62}$ Neben der Aufgabe der - im weitesten Sinn Völkerverständigung sollten die Zentren auch im praktischen Sinn an die Hilfsaktionen der Vergangenheit anknüpfen. Die Quäker wollten „faith and works“ verbinden, mit dem Ziel, überall, wo sie auftraten, zu zeigen, „that there are people in other countries who care“. ${ }^{63}$ Auch wenn diese Funktion in den folgenden Jahren immer mehr in den Hintergrund rückte, wurden die „goodwill centres“ auch in den folgenden Jahren in allen AFSC-Publikationen als wichtiges Werkzeug porträtiert, mit dem Ziel „of applying the Quaker testimony of peaceful relations between governments and peoples“. Insbesondere dienten sie darüber hinaus als beständige Referenzen für den Standpunkt der Quäker in den großen internationalen Fragen der Zeit und umgekehrt als Medium, durch welches das

60 Memorandum for Committee on Interpretation and Publicity 1926, in: AFSCA, AFSC Minutes 1926.

61 Über die Arbeitsweise hieß es 1924: „Letters of introduction are given to prominent people who are expecting to travel in foreign countries, so that they can be put in touch with interested people in those countries. The object is to increase the spirit of goodwill in the world and to disseminate information on those questions that are of interest to the people of every nation, and to demonstrate, by practical service the Christian way of life." In: International Centers of Goodwill, in: AFSC-Bulletin (1924), 4.

62 International Centers of Goodwill, in: AFSC-Bulletin (1924), 4.

63 International Centers of Goodwill, in: AFSC-Bulletin (1924), 4. 
AFSC seine Interpretation der weltpolitischen Ereignisse innerhalb der Society of Friends verbreitete. ${ }^{64}$ Überhaupt war der Begriff der „interpretation“ - in beide Richtungen, gegenüber der Welt und den Quäkern zu Hause - der Schlüsselbegriff, der sich als roter Faden durch alle Veröffentlichungen zog. Auch im Reorganisationsplan von 1929, der die „Quaker outposts“ vor allem als Medium „for better international understanding and the united effort of American Quakerism along new frontiers" hervorhob, nahm dieser Begriff eine zentrale Stellung ein. ${ }^{65}$

Über den konkreten Nutzen und das Ziel der Botschaften schieden sich trotzdem die Geister. Ganz entlang der Linien der Auseinandersetzung der frühen 1920er Jahre um den konkreten Gehalt der tieferen Botschaft, welche das AFSC mit seiner Hilfe verbreiten wollte, sahen einige die embassies als Mittel, um message work in einem durchaus evangelikalen Sinn zu betreiben, Seelen zu retten und neue Quäker zu gewinnen. Die Mehrzahl im AFSC lehnte hingegen diese Art der Missionstätigkeit ab. Für sie kam allenfalls in Frage, die Botschaften als Zentren zu unterhalten, in denen sich Interessierte und Sympathisanten mit den Werten der Quäker vertraut machen konnten, jedoch ausdrücklich nicht mit dem Ziel, sie für den Quäkerglauben zu gewinnen. ${ }^{66}$ Da auch zwischen Briten und Amerikanern unterschiedliche Ansichten herrschten, blieb der Zweck der Zentren in vielerlei Hinsicht eine offene Frage beziehungsweise unterschied sich die Praxis der message work von einer Institution zur anderen teils erheblich.

Auf seiner Reise durch Europa fand Clarence Pickett im Frühjahr einen Flickenteppich quäkerlicher Aktivitäten vor: Großen Zentren wie in Berlin, Wien und Paris standen Außenposten wie die in Warschau und Moskau gegenüber, die wenig mehr als ein loser Zusammenschluss einer Handvoll Quäker in einer in

64 „To interpret to the country where the centre is located the best of the life and ideas of other nations and likewise to interpret to the other nations the best of the life and ideas of the people whom those connected with the centre come to understand and know", hieß es in einem Flugblatt von 1927. AFSC Service, in: AFSC-Bulletin (1927).

65 „The establishment of Quaker outposts in other countries shall serve not merely as channels for interpreting quakerism but also as media of an emerging Christian social science conscience (...). Foreign service work will continue as at present but more time should be given to interpreting to Friends and others in this country the attitude and problems of those countries in which our work is located. The foreign centers should also be kept informed of the trends in this country on questions affecting international relationships.“ The Reorganization Plan in brief, in: AFSCBulletin 72 (1929).

66 „(T)he American Friends Service Committee has felt that in order to cultivate friendship between nations special efforts should be made to keep in touch with those who have turned to Friends for an answer to some of the great questions in their souls. There is no desire on the part of the Friends to establish Friends Meetings in these various countries, but rather to cultivate such a spirit as will make war less likely and bring the people of the world closer together." The Reorganization Plan in brief, in: AFSC Bulletin 72 (1929). 
jeder Hinsicht „un-friendly“ Umgebung waren.$^{67}$ Die Spannung zwischen verschiedenen Konzeptionen der message work wurde hier greifbar: Im Gegensatz zu Polen und der Sowjetunion, wo Missionstätigkeit von vornherein - aus unterschiedlichen Gründen - unmöglich war, waren die Zentren in Paris, Berlin und Wien zumindest in bescheidenem Ausmaß zu Anlaufstellen für die kleinen, oftmals im Gefolge der Hilfseinsätze erst entstandenen beziehungsweise gewachsenen Quäkergemeinden im jeweiligen Land geworden. Gemeinsam war allen Zentren, dass sie ursprünglich als Orte ,internationaler“, das hieß im Wesentlichen angloamerikanischer Zusammenarbeit angelegt waren. Die beiden Zentren, die dabei am ehesten diesem Ideal entsprachen, waren jene in Berlin und Wien. Beide standen unter angloamerikanischer Leitung und dienten sowohl als Kontaktpunkt für Quäker und spirituell Interessierte als auch als Ort der Begegnung für die unterschiedlichsten mit den Quäkern verbundenen Menschen, sogenannte „friends of the Friends“ - überwiegend mit „säkularen“ Anliegen, darunter alle Arten von Pazifisten, Reformpädagogen, Sozial- und Lebensreformern im weitesten Sinn. ${ }^{68}$

Von allen Quäkerbotschaften war das britisch-amerikanisch-deutsch geleitete International Center in Berlin dasjenige, bei dem das AFSC von Anfang an am meisten Engagement zeigte. Ausschlaggebend war die Kontinuität über die Kinderspeisungen, die anders als etwa in Wien eine rein amerikanische Unternehmung gewesen waren, und dass sich hier der Versöhnungsaspekt am ehesten widerspiegelte. Aus Sicht des AFSC war Berlin - und Deutschland generell (neben Moskau, wo die Pläne jedoch nie über Anfänge hinausgelangten) am ehesten geeignet, message work in einem für alle Seiten akzeptablen, sprich: nichtevangelikalen Sinn, zu betreiben. 1924 hatte das AFSC eigens zu diesem Zweck den Theologen und Schüler Rufus Jones', Thomas Raymond Kelly nach Berlin entsandt. Laut seinem Biografen Guy Aiken hatte er den Auftrag, „to encourage and nurture pacifism, temperance, German Friends, ,friends of the Friends' and international understanding and cooperation" ${ }^{69}$ Als Clarence Pickett das Zentrum in Berlin 1930 besuchte, war Kelly bereits wieder zurück in den USA, aber an der Ausrichtung hatte sich nichts geändert. Das Internationale Zentrum unterhielt einen kleinen Studentenclub und bildete eine Kontaktstelle für pazifistische und reformerische Unternehmungen aller Art. Es arbeitete eng mit der Deutschen Mittelstelle für Quäkerarbeit zusammen, die sich unter der

67 Clarence Pickett Trip to Europe April - June 1930, in: AFSCA, Clarence Pickett Journals 1920 1936 (Trip to Europe).

68 Quaker Embassies. A Survey of Friends Service in Europe since 1919 (London: Friends House, 1933)

69 Aiken, „Social Christianity,“ 61. 
Leitung Elisabeth Rottens um „educational work on the basis of Quaker ideas“ bemühte. Rotten war dabei nur eine von vielen, die den Quäkern seit der Zeit der Kinderspeisungen verbunden geblieben waren. Auch die Kontakte zur Jugendbewegung spielten noch eine Rolle. ${ }^{70}$ Das Zentrum unternahm keine missionarischen Anstrengungen, sondern verstand sich lediglich als Anlaufstelle für die kleine (etwa 500-köpfige) Gruppe deutscher Quäker, deren zentrales Gremium die Deutsche Jahresversammlung war. Hinzu kam die größere Gruppe der „friends of the Friends“, also Personen, die sich dem Quäkertum verbunden fühlten, ohne selbst der Glaubensgemeinschaft formal beizutreten. Die Beziehungen zu dieser äußerst heterogenen Gruppe zu pflegen - Pickett beschrieb die Zusammenarbeit gar enthusiastisch als ,one of the greatest religious experiments that any group anywhere in the world is trying out“ -, war aus Sicht des AFSC eine zentrale Aufgabe des Zentrums, um den Einfluss quäkerlichen Denkens in Deutschland zu stärken und zu vergrößern. ${ }^{71}$

Außerdem pflegte das Zentrum über einen weiteren amerikanischen Repräsentanten, Gilbert MacMaster und seine deutsche Frau Margarethe (Lachmund), eine Reihe von Kontakten in Deutschland und darüber hinaus. MacMaster unterhielt ein breites Netzwerk in pazifistischen Kreisen, war bekannt mit Vertretern von Wohlfahrtsvereinigungen unterschiedlicher Couleur und denen von jüdischen und exilrussischen Organisationen im Reich. Im Streit um die deutschen Minderheiten in Polen hatte MacMaster eine Vermittlerrolle gespielt, und in Zusammenarbeit mit dem Quäkerzentrum in Warschau auch eine Reihe von ,Versöhnungskonferenzen“ sowie deutsch-polnische Jugendcamps organisiert. MacMaster war in der Folge auch immer wieder von der amerikanischen Botschaft in Minderheitenfragen als Experte zu Rate gezogen worden. Diese persönlichen Kontakte hatten dem Berliner Zentrum insgesamt eine Stellung verschafft „of being much looked to for counsel, guidance, vision and hope“. ${ }^{72}$

Das Zentrum in Wien dagegen blieb eine Domäne der britischen Quäker. Als Pickett es im Frühjahr besuchte, fungierte es vor allem als Begegnungszentrum für Studenten. In dieser Hinsicht war es sogar einzigartig, da es nach Picketts

70 So wurde in Clarence Pickett etwa auf den preussischen Ministerialrat Heinrich Becker verwiesen, der den Quäkern über die Jugendbewegung verbunden war. Die Jugendbewegung, so Pickett sei mittlerweile zwar zu einer unbedeutenden Grösse geschrumpft, aber ihre vormaligen Protagonisten erlangten nun zunehmend einflussreiche Positionen, „slowly but surely remaking with real vision, the social life of Germany"."'The state, poetry, social legislation and politics are slowly feeling the effect.“ Eintrag 18/04/1930, in: AFSCA, Clarence Pickett Journals 1920-1936 (Trip to Europe 1930).

71 Eintrag 16/04/1930, in: AFSCA, Clarence Pickett Journals 1920-1936 (Trip to Europe 1930). 72 Eintrag 16/04/1930, in: AFSCA, Clarence Pickett Journals 1920-1936 (Trip to Europe 1930). 
Bericht der einzige Treffpunkt für Studenten war, der politische und sonstige Trennlinien $\mathrm{zu}$ überwinden vermochte. In der ansonsten zwischen deutschnationalen, katholischen, jüdischen und sozialdemokratischen Vereinigungen aufgeteilten universitären Landschaft boten die Quäker einen Ort der Begegnung für alle. Pickett war beeindruckt von dieser Arbeit, auch weil das Wiener Zentrum nicht nur für Österreich, sondern quasi als „house of bishop for Southeastern Europe“, mithin für die verstreuten, kleineren Gruppen von Quäkern und „friends of Friends“ in Belgrad, Sofia oder Bukarest und sogar bis nach Griechenland Strahlkraft besaß. ${ }^{73}$

Von einer solchen Situation waren die Zentren in Warschau, Prag und Moskau weit entfernt. In Polen war ein anfänglich - im Gefolge der Hilfsaktionen in den frühen 1920er Jahren - florierendes Zentrum zur Bedeutungslosigkeit geschrumpft, wobei die feindselige Haltung des Staates im überwiegend katholischen Polen die Arbeit für protestantische Gruppen (und als solche wurden die Quäker in erster Linie wahrgenommen) enorm erschwerte. Als Pickett hier eintraf, war die Arbeit in Polen faktisch zum Erliegen gekommen. ${ }^{74}$ Gleiches galt aus ganz anderen Gründen für das Moskauer Büro, in dem zu diesem Zeitpunkt noch drei Personen als letzter Rest der großen Hilfsmission in Russland die Stellung hielten. Picketts Besuch ereignete sich rund ein Jahr, bevor die Quäker ihre Arbeit in Russland endgültig einstellten und Alice Davis und Olga Danilovsky in die USA zurückkehrten, um schließlich in der homestead-Bewegung ein neues Betätigungsfeld zu finden. Picketts Bericht über den Besuch in Moskau - noch in der Hoffnung, eine weitere Betätigung vor allem beim Aufbau von Kindereinrichtungen für das verbliebene Personal finden zu können (auch Anna Haines zeigte Interesse, in ihre alte Funktion beim Aufbau eines Krankenpflegewesens zurückzukehren) - bietet trotz seiner Ergebnislosigkeit ein faszinierendes Zeugnis: Die Faszination für die gesellschaftlichen und wirtschaftlichen Errungenschaften des Sowjetregimes war in Picketts Bericht deutlich spürbar, trotz des allgegenwärtigen anti-religiösen Aktivismus, den er staunend beobachtete: „Here one could see everything: fear, suffering, hope, achievement, belief in the future; abounding energy which had been released by the revolution and the unqualified belief in the future of Russia. “75

73 Eintrag 05/05/1930, in: AFSCA, Clarence Pickett Journals 1920-1936 (Trip to Europe 1930). 74 Eintrag 16/04/1930, in: AFSCA, Clarence Pickett Journals 1920-1936 (Trip to Europe 1930). 75 Unter Anleitung des Besucherdienstes Vox besuchte Pickett Fabriken, Krankenhäuser und ein anti-religiöses Museum. Ergänzt wurden seine Eindrücke durch Begegnungen mit Tolstoianern, zu denen die Kontakte nicht abgerissen waren, sowie den Vertretern ausländischer Presse in der Sowjetunion. Nachtrag zum Reisebericht von 1930: in: AFSCA, Clarence Pickett Journals 1920 1936 (Trip to Europe 1930). 
Eine Sonderrolle unter den Goodwill Centres nahm dagegen das internationale Quäkerzentrum ein, das Amerikaner und Briten 1926 gemeinsam im schweizerischen Genf am Sitz des 1919 gegründeten Völkerbundes eröffnet hatten. Der Leiter des Zentrums, Bertram Pickard, war ein britischer Quäker und in den frühen 1920er Jahren enger Mitarbeiter Carl Heaths gewesen. Als Clarence Pickett Genf im Rahmen seiner Europatour besuchte, war es Pickard bereits gelungen, das Zentrum als eine feste Größe im Umfeld der vielen international orientierten Gruppen und Vereinigungen zu etablieren, die sich am Genfer See um den Völkerbund angesiedelt hatten. ${ }^{76}$ Er unterhielt enge Kontakte mit Institutionen des internationalen Lebens am Genfer See wie dem (Graduate) Institute for International Studies unter der Leitung William Rappards, der World Student Christian Federation oder der Save the Children International Union und übte seit 1929 auch die Position eines Ehrensekretärs des Verbandes privater und halboffizieller internationaler Organisationen aus. ${ }^{77}$ Unter Pickards Führung hatte sich das Zentrum auf diese Weise rasch zu einer Art Beobachtungsposten der Weltpolitik entwickelt und diente als Anlaufstelle insbesondere für pazifistische Gruppen und betrieb zu diesem Zweck auch eine eigene Studentenherberge. ${ }^{78} \mathrm{Ab}$ 1929 bot das Zentrum darüber hinaus einen eigenen Quäkernachrichtendienst, ${ }^{79}$ der regelmäßig über die Arbeit des Völkerbundes und andere internationale Themen berichtete und den Quäkern neue Möglichkeiten der „Interpretation“ verschaffte. „Geneva might well be largely a meeting place of national organizations - instead we are helping it to create something new - an international quality of life“, bemerkte Pickett in seinem Tagebuch. ${ }^{80}$

Das Genfer Quäkerzentrum ist ein interessantes Studienobjekt, um die Merkmale, Spannungen und Widersprüche im Internationalismus des AFSC während der Zwischenkriegsjahre zu diskutieren. Der Blick auf Genf wirft ein Schlaglicht auf das breite Spektrum der Ansichten zur internationalen Politik im AFSC im Speziellen und besonders auf das Verhältnis zum Völkerbund und dem von ihm repräsentierten Prinzip der kollektiven Sicherheit. Eine Gruppe britischer Quäker, vertreten insbesondere durch Carl Heath und Ruth Fry, stand dabei für einen „spirituellen Internationalismus“, der für eine quäkerspezifische, gewalt-

76 Waugh, „Quakers, Peace and the League of Nations: The Role of Bertram Pickard.“

77 The Quaker Student Hostel, in: AFSC-Bulletin 89 (1931)

78 Waugh, „Quakers, Peace and the League of Nations: The Role of Bertram Pickard.“; Bertram Pickard, Pacifist Diplomacy in Conflict Situations: Illustrated by the Quaker International Centers (Philadelphia: Pacifist Research Bureau, 1943); Alison M. Bush, ed. Bertram Pickard of Geneva: His Journal Letters from USA in 1935 and 1937 (1999).

79 Waugh, „Quakers, Peace and the League of Nations: The Role of Bertram Pickard.“

80 Eintrag 16/05/1930: Clarence Pickett Journals 1920-1936 (Trip to Europe 1930). 
freie Diplomatie eintrat, auf das persönliche Beispiel des Einzelnen setzte und den Völkerbund als Repräsentanten einer auf dem Gewaltprinzip fußenden internationalen Ordnung ablehnte. Die Gegenposition, die etwa von Bertram Pickard vertreten wurde, plädierte dagegen für eine begrenzte Mitarbeit der Quäker innerhalb der bestehenden Ordnung, deren Fehlerhaftigkeit es bis zu einem gewissen Grad zu akzeptieren gelte. ${ }^{81} \mathrm{Zu}$ Anfang der 1930er Jahre schieden sich die Geister insbesondere an der Frage der Sanktionen gegen solche Länder, die gegen die vom Völkerbund vertretenen Prinzipien der kollektiven Sicherheit verstießen. Für die spiritual internationalists war jede Art von Sanktionen, gleich ob militärischer oder wirtschaftlicher Natur, ein kriegerischer Akt. In dieser Sichtweise mussten Quäker solche Zwangsmaßnahmen ebenso ablehnen, wie sie gegen die alliierte Blockade gegen Deutschland nach dem Ersten Weltkrieg aufgetreten waren. ${ }^{82}$

Leicht lassen sich diese Auseinandersetzungen mit jenen verknüpfen, in denen zeitgleich um die Position der Quäker beim Umgang mit industriellen (oder anderen gesellschaftlichen) Konflikten im eigenen Land gerungen wurde. Einige wie Henry Cadbury, die gleichzeitig einen aktiven Part in der Friedensbewegung ausübten, waren grundsätzlich skeptisch gegenüber Zwangsmaßnahmen jeder Art, ob auf nationaler oder internationaler Ebene. Dennoch war zur selben Zeit die Haltung des AFSC zum Völkerbund im Allgemeinen positiv. Eine Rolle spielte dabei wohl auch, dass sich das AFSC damit im Einklang mit den Positionen anderer liberaler christlicher und jüdischer Gruppen vor allem an der Ostküste sah, die sich in der Regel für einen Eintritt der USA in den Völkerbund einsetzten. Von Mitte der 1920er Jahre an hatte das AFSC versucht sich anhand konkreter weltpolitischer Ereignisse als Stimme der amerikanischen Quäker in internationalen Fragen zu positionieren. So veröffentlichte es wiederholt Stellungnahmen und Pamphlete zur Flottenpolitik und den internationalen Abrüstungsverhandlungen. ${ }^{83}$ Parallel begann die peace section ab 1930 damit an Colleges im ganzen Land sogenannte Institutes of International Relations für Studierende abzuhalten, ein „experiment“ bei dem „the problem of world peace“ aus vier unterschiedlichen Blickwinkeln, ,the political, the economic, the sociological and the spiritual“ unter Beteiligung prominenter Wissenschaftler, Aktivisten und Politiker diskutiert wurde. Bei den in der Regel einwöchigen Seminaren, die im Laufe der

81 Pickard, Pacifist Diplomacy in Conflict Situations: Illustrated by the Quaker International Centers.

82 Waugh, „Quakers, Peace and the League of Nations: The Role of Bertram Pickard.“

83 Friendship or Preparedness? Treaties or Cruisers? Arbitral Decisions or War? in: AFSC-Bulletin 76 (1928); The Position of the Society of Friends with Regard to War, in: AFSC-Bulletin 77 (1928). 
1930er Jahre sukzessive ausgebaut wurden, nahm der Völkerbund eine zentrale Stellung in der Diskussion ein. ${ }^{84}$

Damit wurde erneut und in steigendem Maß deutlich, dass das AFSC auch in internationalen Fragen keineswegs die Haltung der Society of Friends als Ganzer repräsentierte, in der isolationistische Positionen weit verbreitet waren. Auch aus diesem Grund erkannten Clarence Pickett und sein Kollege Gilbert MacMaster den möglichen Nutzen des Genfer Zentrums: Mit seiner Hilfe konnte Friends aller Richtungen in den USA eine internationale Perspektive auf die Probleme der Zeit aus Quäkersicht eröffnet werden. ${ }^{85}$

Als Clarence Pickett im Juni 1930 in die USA zurückkehrte, war er mehr denn je davon überzeugt, dass die Quäker in der Welt gebraucht wurden. In den Gemeindebauten des „Roten Wien“ und in den Fabrikstädten der Sowjetunion hatte er zwar Ansätze gesehen, die „prophetic of something new, intelligent and better“ seien und die ihm in manchen Aspekten als vorbildlich auch für das eigene Land erschienen. Anderswo jedoch sah er vor allem Orientierungslosigkeit und einen aggressiven Nationalismus, der sich im Zeichen der wirtschaftlichen Krise überall wieder Bahn brach und die zarte Pflanze der Friedensbewegung in Europa zu ersticken drohte. „As to Quaker Work“, schloss er seinen Tagebuchbericht, „tho (sic!) it is small and often suffers from isolation and lack of support, I honestly believe that it represents the three elements most needed in the world I saw": ein soziales Bewusstsein, das spirituelle Aspekte nicht vernachlässigte, die grundsätzliche Anerkennung der Würde des Individuums, auch und gerade über politische Trennlinien hinweg, und schließlich eine Religion, die sich auf „das von Gott in jedem Menschen“ konzentrierte. Wenn es gelänge, in diesem Geist, die in Europa geschaffenen Institutionen für weitere 20 Jahre als lebendige Zentren des Austauschs zu erhalten, so Pickett mit großer Zuversicht, „who can calculate how much of a part they may play in not only bringing peace, but new meaning to the

84 Zum ersten International Institute of International Relations, AFSC Annual Report 1931, 12. Zu den ersten Teilnehmern zählten etwa Reinhold Niebuhr und Frederick Libby, Norman Thomas und Henry Hodgkin.

85 Für das AFSC als eine US-amerikanische Organisation erfüllte das Zentrum schließlich noch einen weiteren wichtigen Zweck, indem es einen Kontaktpunkt mit den in Genf vertretenen Amerikanern im Völkerbundsekretariat und in Nicht-Regierungs-Organisationen herstellte, weil die USA selbst kein Mitglied im Völkerbund war. So etwa zur Rockefeller Foundation und zu Raymond Fosdick oder zu Arthur Sweetser. Eintrag 16/05/1930, in: AFSCA, Clarence Pickett Journals 1920 - 1936 (Trip to Europe 1930). 
life of the world“. ${ }^{86}$ Wie nach dem Ersten Weltkrieg, sollte es in Deutschland sein, wo dieser Anspruch erstmals ernsthaft auf die Probe gestellt wurde.

86 Eintrag 16/05/1930, in: AFSCA, Clarence Pickett Journals 1920-1936 (Trip to Europe 1930). 